IZA DP No. 4744

The Effect of Enclave Residence on the Labour Force Activities of Immigrants in Canada

Jiong Tu

February 2010 


\title{
The Effect of Enclave Residence on the Labour Force Activities of Immigrants in Canada
}

\author{
Jiong Tu \\ Human Resources and Skills Development Canada - Labour Program \\ and IZA
}

\section{Discussion Paper No. 4744 \\ February 2010}

\author{
IZA \\ P.O. Box 7240 \\ 53072 Bonn \\ Germany \\ Phone: +49-228-3894-0 \\ Fax: +49-228-3894-180 \\ E-mail: iza@iza.org
}

Any opinions expressed here are those of the author(s) and not those of IZA. Research published in this series may include views on policy, but the institute itself takes no institutional policy positions.

The Institute for the Study of Labor (IZA) in Bonn is a local and virtual international research center and a place of communication between science, politics and business. IZA is an independent nonprofit organization supported by Deutsche Post Foundation. The center is associated with the University of Bonn and offers a stimulating research environment through its international network, workshops and conferences, data service, project support, research visits and doctoral program. IZA engages in (i) original and internationally competitive research in all fields of labor economics, (ii) development of policy concepts, and (iii) dissemination of research results and concepts to the interested public.

IZA Discussion Papers often represent preliminary work and are circulated to encourage discussion. Citation of such a paper should account for its provisional character. A revised version may be available directly from the author. 
IZA Discussion Paper No. 4744

February 2010

\section{ABSTRACT \\ The Effect of Enclave Residence on the Labour Force Activities of Immigrants in Canada}

It has been well documented that immigrants' clustering of residence in large cities has been associated with the creation of a number of ethnic enclaves. The intensive exposure to ownethnic population could affect immigrant labour market involvement positively or negatively. However, no extant Canadian research has provided empirical evidence on the sign of these enclave effects. In this paper, I use the 1981-2001 Censuses to estimate the impact of residence in ethnic enclaves on male immigrants' labour force participation rate and employment probability. For recent immigrants who arrived in Canada within the preceding ten years, the intensity of enclave residence is negatively associated with their labour force participation rate, but positively related to their employment probability in all censuses. However, living in an enclave has no significant effect on the labour force activity of older immigrants who have lived in Canada for more than twenty years. Since immigrants could be attracted to areas with more job opportunities and hence enlarge the size of an enclave, the estimated effects from probit regressions might be positively biased. I then use instrumental variable (IV) method to address this endogeneity problem, and the IV estimates are consistent with the probit regression results.

JEL Classification: F22, J15, J21, J61

Keywords: immigrant, ethnicity, enclave, labour force participation, employment, Canada

Corresponding author:

Jiong Tu

Research and Data Development

Human Resources and Skills Development Canada - Labour Program

165 Hotel de Ville

Gatineau, QC K1A0J2

Canada

E-mail: jtu@lakeheadu.ca 


\section{Introduction}

Canada is one of the world's largest host countries for immigrants. According to the 2006 Census, about one fifth of the Canadian population are foreign born. Given the importance of immigrants' labour market performance to the health of Canadian economy, there has been an abundance of research on immigrant earnings and their convergence with those of native-born Canadians, a process known as assimilation. Baker and Benjamin (1994) and Bloom et al. (1995) find that immigrants who arrived in the 1970s have low entry earnings and low assimilation rates, and that immigrants cannot catch up in earnings with the native-born. Hum and Simpson (2000), Frenette and Morisette (2003) and Gray et al. (2003) update the literature using more recently available data. They still do not observe evidence of assimilation during the 1990s, in spite of new immigrants' rising educational attainment.

In addition to earnings, it is equally important to study immigrant labour force activities, because the prerequisite of earnings assimilation is to participate in the labour force and be employed. However, according to the Canadian censuses, young and recent immigrants have lower labour market involvement than old and earlier cohorts (as shown in Section 3). Additionally, after the 1987 policy change that skilled workers no longer required a pre-arranged job position to apply for permanent residence, the average number of landing immigrants drastically increased to over 200,000 per year with a large proportion from Asian countries such as China, India and Pakistan. Owing to the increasing diversity in ethnic and cultural background of immigrants, it is reasonable to expect their labour force attachment to change.

An enclave is a minority foreign-born ethnic or cultural group living as an entity 
within the territory of the host country. It is well documented by economists, for example Balakrishnan and Hou (1999), Hou and Picot (2003) and Warman (2007), that immigrants in Canada, like those in other major host countries, tend to cluster in areas that have a large stock of immigrants with the same ethnicity, and build up their enclaves: examples would be China Town or the Jewish community in Toronto. There are many reasons for immigrants to live in enclaves. Bartel (1989) suggests that new immigrants usually favour a city that serves as the port of entry, hosts a great intensity of co-ethnic immigrants, and provides more job opportunities. Historically, the port city factor is crucial in the establishment of an enclave, while co-ethnicity and job opportunities become more important during its development.

An enclave provides immigrants with social networks and ethnic goods at low cost. By speaking a common language, immigrants in enclaves can quickly build up networks, and share knowledge about living and working in the host country. Moreover, immigrants from non-traditional source countries have brought a wide variety of food, clothes and even holidays that are different from the Canadian tradition. Chiswick and Miller (2002) term the goods and services that are only consumed by some specific ethnic groups and not by natives as "ethnic goods". Due to economies of scale, the average cost of providing ethnic goods may decrease when the size of the ethnic group in an area grows. As a result, the price of ethnic goods may be more competitive in a large ethnic enclave than in a small one.

Given the particularity of immigrants' residential behaviour, researchers try to explore the effect of living in an ethnic enclave on immigrant earnings using data from Canada (Warman 2007), the U.S. (Borjas 2000, Chiswick and Miller 2002, and Chowdhury and Pedace 2007) and Europe (Clark and Drinkwater 2002 and Edin et al. 
2003). However, there is little research on the relationship between immigrant residential segregation and their labour force attachment. Hou and Picot (2003) briefly touch upon this question in a study on ethnic enclaves using the 1981-1996 Canadian Censuses. They conclude that the correlation between the intensity of own-ethnicity neighbours and an immigrant's probability of employment is negative but statistically insignificant in most cases. Since they sample the three largest visible minority groups, namely Chinese, South Asian and Black, in Toronto, Montreal and Vancouver, their findings represent only part of the complete picture. Extensive research on more ethnic groups across the whole country is required to obtain a broader view. In order to fill this knowledge gap, I use a sample of all major ethnic groups in Canada to analyze the impact of enclave residence on immigrant labour force participation rate and employment likelihood.

This paper is structured as follows. Section 2 provides a literature review. In Section 3, I describe the data and conduct a cross tabulation analysis. The basic econometric model of immigrant labour force activities is outlined in Section 4 and the regression results are presented. Section 5 explains the complications of the econometric model, and provides a solution to the problem. The final section concludes.

\section{$2 \quad$ Literature on Ethnic Enclaves}

Economic research often uses residential segregation and ethnic network to explain the development of immigrant earnings and employment. However, the direction of the effect of enclave residence is undetermined.

On the one hand, the demand for ethnic goods in large enclaves provides business opportunities and hence directly increases the demand for immigrant workers with 
ethnic-specific skills. One important incentive for immigrants to work in these ethnic companies is that in most cases, they are not required to possess the abilities specific to success in Canadian labour market, such as proficiency in official languages. In this way, enclave residence may increase the odds for their initial survival in the labour market. As evidence, Borjas (1986) finds that immigrants have higher self-employment rates than natives due to the "enclave effects". In addition, an indirect positive effect comes from the social network that is readily available to new residents in ethnic enclaves. Immigrants, no matter how proficient in official languages, can benefit from the job information obtained through the ethnic network. Goel and Lang (2009) study the effect of social ties on immigrant job search using data from the Longitudinal Survey of Immigrants to Canada (LSIC). They find that the job arrival rate is faster for immigrants who are closely tied to their network.

On the other hand, enclave residence could also have a negative effect on immigrant labour market performance. When the size of an enclave grows, more unassimilated immigrants enter the enclave and compete with existing immigrants for jobs in ethnic companies. An ethnic company may then possess monopsonistic power against those who lack the host-country-specific skills. To maximize its profit, the company is likely to hire fewer workers and pay less than in a competitive labour market. Moreover, enclaves may segregate immigrants from the mainstream and reduce their incentive to acquire Canadian-specific skills. Lazear (1999) discovers a negative correlation between living in minority language enclaves and improvement of proficiency in official languages for immigrants in the U.S., and Chiswick and Miller (2002) find similar results using Canadian data. When immigrants living in ethnic enclaves do not 
accumulate as many language skills as those living outside, their work experience and other human capital may not be easily transferable into productivity in the host country. In this way, enclave residents' job opportunities are largely restricted within the confines of ethnic firms, and their employment likelihood outside enclaves then becomes very low.

Given the pros and cons of enclave residence, its net effect on immigrant labour market involvement is theoretically ambiguous. Therefore, a number of researchers attempt to address this question by empirical approaches. Studies using U.S. data have shown a negative relationship between enclaves and immigrant wage assimilation. Borjas (2000) measures enclave by ethnic segregation and finds that male immigrants' residence in enclaves harms their wage growth. Chiswick and Miller (2002) use the concentration of home languages to measure enclave intensity and find negative effect on earnings as well. Warman (2007) applies Borjas’s (2000) method to the 1981-2001 Canadian Census data and obtains a similar result.

Unlike earnings, research on other aspects of immigrant labour market outcomes does not yield pessimistic results. For example, Balakrishnan and Hou (1999) find a weakening correlation between residential and occupational segregation by ethnicity during the 1980s. Although immigrants still tend to live in enclaves, they become more likely to work in higher social status occupations. According to Hou and Picot's (2003) research, the effects of enclave residence at the census tract level on immigrant employment and occupational segregation vary across ethnic groups. For example, living in an own-ethnicity intensive neighbourhood lowers a black immigrant's likelihood of being employed and increases his probability of working in an ethnically segregated occupation, whereas the effect is not statistically significant in either way for a Chinese 
immigrant. These studies provide an alternative angle of analyzing immigrant enclave residence and labour market assimilation.

\section{$3 \quad$ Data and Statistical Summary}

The datasets that I use in this paper are drawn from the 1981, 1986, 1991, 1996 and 2001 Canadian Census Public Use Microdata File (PUMF). I restrict my sample to male immigrants aged 25-54 who are not born in an English or French speaking developed country. Thus, those born in the U.S., the U.K., Ireland, Australia, New Zealand and France are excluded due to their similarity to native-born Canadians in terms of languages and culture. I focus my study on males only because female labour supply is usually complicated by their roles in non-market work at home. The age restriction is set to the primary working ages in order to exclude individuals who are pursuing postsecondary education and those who are eligible for early retirement during the survey year. I also drop observations of Atlantic Provinces and the Territories because of the small representation of immigrants in these areas. All wages and earnings are deflated by Consumer Price Index (CPI) based on the 1992 Canadian dollar.

Descriptive statistics show that younger immigrants perform worse than older ones. I plot the age profile of immigrant participation rate and employment rate relative to same-aged natives by birth-year group in Figures 1 and 2. Immigrants born before 1951 have higher participation and employment rates than natives (that is, their relative rates are positive in the figures), while those born after 1951 are worse off than natives. Figure 3 and 4 present the immigrant- native differences in labour force activities by immigrant arrival cohort. Immigrants who arrived more recently, say after 1980, have lower relative 
participation and employment rates than those who migrated before 1980. However, as recent cohorts' time in Canada increases, their relative labour force activities tend to converge with the earlier cohorts. The fact that older and earlier immigrants perform better than younger and more recent cohorts implies assimilation through the improvement of labour market attachment.

\subsection{How to Measure Ethnic Enclave?}

I measure the ethnic enclaves by an exposure index that is commonly used in this type of literature (Borjas 2000 and Warman 2007). Let $M$ be the number of immigrants and $P$ the total population. The exposure index of enclave is then the share of population in a census metropolitan area (CMA) $c$ that belongs to an ethnicity $j$ :

$$
\text { ENCLAVE }=M_{c j} / P_{c}
$$

I include both men and women of all work statuses and all ages to calculate the index, because each person's human capital and activity, regardless of his or her own labour market activity, can help construct the ethnic economy and network in an enclave and, in turn, affect a resident's labour force activities.

The geographic area is defined by CMA because the social network between immigrants and their ethnic groups largely depends on their mobility. According to Warman (2007), on the one hand, bus and subway services provide immigrants with a means of low-cost transportation within a city. On the other hand, the distance between CMAs is large enough to make intercity commuting relatively inconvenient. Moreover, new immigrants often build up their network through the use of public services or immigrant-assistance programs, such as libraries or language training programs. Since 
most of these programs are provided and manipulated at the city level, it is reasonable to assume that immigrants usually interact with ethnic friends within a CMA. Although census tract is sometimes more accurate in measuring the neighbourhood characteristics (Hou and Picot 2003), it is too strong of an assumption that immigrants interact more with their neighbours than with friends living in a distant community of the same city.

Table 1 lists enclaves with the highest exposure index in the 2001 Census by ethnicity and CMA. Toronto is the largest host city of ethnic enclaves, followed by Montreal and Vancouver. The economic environment in these cities may be one reason for immigrants to reside there. Besides, Vancouver magnetizes immigrants from Asia by its mild weather and vicinity of the Pacific Ocean. As discussed before, the large stock of existing immigrants in these cities then attract more immigrants from the same country of origin. Except for a few traditional source countries like Germany and Italy, immigrants from the new source countries, such as China, India and the Philippines have established most of the large ethnic enclaves. Due to the cultural and economic differences between these developing countries and Canada, immigrants from there are likely to cluster together and form a shelter against cultural shock. Limited by data availability, it is not possible to track all ethnicities from 1981 to 2001. However, an intercensal comparison of ethnic groups shows that Arab, Chinese, Filipino, Italian, and Portuguese enclaves continuously rank high in the list of exposure indices.

\subsection{Who Are More Likely to Live in Ethnic Enclaves?}

As discussed in the previous sections, there are a variety of reasons for immigrants to live in ethnic enclaves. Although a detailed analysis is beyond the range of 
this paper, I use a statistical summary to illustrate immigrant residential distribution.

Table 2 reports the distribution of enclave residence by immigrant socio-economic characteristics. I order the exposure index for immigrants from non-English or French speaking countries and divide them into three equal-sized groups. The lowest one third are called small enclave, and the highest one third are called large enclave. I then calculate the share of immigrants living in each enclave group by their socio-economic characteristics. For example, the first number in the row "High School Graduates” is equal to the number of immigrants with a high school diploma living in a small enclave divided by the total number of immigrant high school graduates. Therefore, the sum of each row in a census panel is 1 . I omit age, marital status and naturalized citizenship, because they do not seem to vary across enclave groups.

Immigrants whose years-since-migration (YSM) is more than 20 may have a high level of assimilation and their share of large enclave residents is lower than 30 percent in most censuses. By contrast, the most recent cohort who arrived in Canada within 10 years is more likely to live in large enclaves, and the likelihood turns as high as 40 percent in 2001. However, it does not necessarily mean that these immigrants have moved out of enclaves, because the exposure index can be lowered when the population in a CMA grows faster than the enclave size.

Traditionally, it is the less-educated immigrants who are more likely to live in ethnic enclaves. In 1986, about 40 percent immigrants with less than high school education choose large enclaves, whereas over 40 percent postgraduate immigrants live in small enclaves. However, during the 1990s, the large inflow of skilled-worker immigrants from Asia has substantially changed the pattern; their high educational attainment and 
preference over large enclaves have raised the proportion of university degree holders living in large enclaves to 40 percent and that of postgraduates to 34 percent in 2001.

Knowledge of one of the official languages does not seem to be correlated with immigrant residential decision. However, those who cannot speak either one of the official languages tend to live in large enclaves.

\subsection{How Do Enclave Residents Perform?}

Table 3 compares the labour market performance of immigrants by the distribution of enclave residence. Means of natives and immigrants from English or French speaking developed countries are listed for reference. For example, the first number in the "Employed" row is the proportion of immigrants living in small enclaves who are employed. The sum of employed, unemployed and not in labour force is equal to 1 in each column.

In most census years, the share of employed is not very different between small and large enclaves. However, those living in large enclaves have lower participation rates and are less likely to be unemployed than those in small enclaves. Overall, enclave residence does not seem to improve immigrants' labour force involvement relative to natives.

Immigrants in large enclaves earn less than those in small enclaves. However, the disparity in annual wages and earnings shrinks over time, partially due to the increasing share of high-skilled immigrants living in large enclaves.

Interestingly, the proportion of large enclave residents working in the same

Census Sub-Division (CSD) is even lower than those in a small enclave. This has two 
implications: (a) living in a large enclave may provide an immigrant with information about job opportunities beyond its geographic confinement; (b) considering immigrants' high dwelling-owning ratios, it may be difficult for them to move close to the place of work. If residents in large enclaves are less mobile than those in small enclaves, the effect of job opportunities on residence decision, that could cause endogeneity problem in the multivariate regression analysis, is moderate. Since CSD is a smaller geographic area than CMA and the majority of people stay in the same CSD as five years ago, it is safe to say that most immigrants choose to live in the same enclave over a long period of time.

In summary, recently arrived immigrants are more likely to live in large ethnic enclaves on arriving in Canada, but they do not seem to fare better than those outside enclaves in terms of labour market involvement and earnings. However, the cross-tabular analysis is based on simple descriptive statistics without controlling for observable socio-economic characteristics. In order to accurately estimate the effect of enclave residence, I need to use multivariate regression methods.

\section{$4 \quad$ Basic Model and Results}

\subsection{Model Specification}

I use a probit model to estimate the effect of enclaves on immigrants' labour force activities. I include male immigrants who are in their primary working age in the labour force participation model, while only those employed and unemployed are sampled in the employment model. For each census year $t$, I run the following regression:

$$
\operatorname{Prob}\left(Y_{i t}\right)=f\left(E N C L A V E_{c j t}, Y_{S M}, X_{i t}\right)
$$


where $Y$ is a binary variable indicating an immigrant's labour force activity, that is, $Y$ equals one for a participant in the labour force participation model and for an employed man in the employment model, and zero otherwise. As defined in the previous section, $E N C L A V E_{c j}$ is the exposure index of immigrants with ethnicity $j$ living in CMA $c$. In addition to regressions with the continuous enclave index, I use a dummy indicating a large enclave whose exposure index is greater than 0.02 which is roughly the 67 percentile (or two thirds). This enclave dummy allows me to estimate the threshold effect of enclave residence at the cut-off level ${ }^{1}$. YSM is a vector of dummies indicating the immigrant years-since-migration group that captures the assimilation effect because immigrants who arrive earlier may have higher labour market attachment than new arrivals. The three YSM groups are 21 years and more (the default), 11 to 20 years, and 10 years and less. In the regressions, I interact either continuous or discrete measure of enclave with YSM to test the effect at different stages of assimilation.

In the above equation, $X$ is a series of socio-economic characteristic variables, including age, education, province, marital status, visible minority status and knowledge of official languages. In the labour force participation model, I add a dummy indicating the presence of at least one unmarried child because it can affect a person's participation decision in two ways: on the one hand, a child will increase the father's opportunity cost of time and the preference over leisure that, in turn, will reduce the participation rate. On the other hand, the presence of a child will also increase the budget constraint and motivate the father to participate in the labour market. Additionally, eligibility of childcare tax benefits can increase a parent's after-tax income and also provide an

${ }^{1}$ I have also used discrete enclave index by dividing the index into a series of equal-width bands and using a vector of dummies to indicate them. Regression results show that only enclaves with an index higher than 0.02 have significant coefficient estimates. 
incentive to participate. Likewise, in the employment model, I include naturalized citizenship as a control variable, because Canadian citizenship will give a candidate some priority in obtaining government jobs.

\subsection{Regression Results of the Labour Force Participation Model}

To simplify the interpretation of the probit regression results of male immigrant labour force participation, I calculate and report the marginal effects of the independent variables in this section. In all regressions, the control variables ${ }^{2}$ have expected signs, for example, the most recent immigrants whose YSM is 10 years and less have a significantly lower probability of participation than those who arrived 20 years ago. The age group variables show that the participation rate peaks at the age $30-39$, and immigrants with higher education are more likely to participate. Compared to Ontario, only immigrants living in Quebec have a significantly lower participation rate. Those who cannot speak either official language and who belong to visible minority have a lower rate, but marriage and the presence of a child have positive effects on participation.

I highlight the estimated marginal effects of the enclave index and its interaction with YSM in Table 4. The enclave index is statistically insignificant in 1991 and before, but it turns significantly negative as of 1996. The marginal effect in 1996 means a 1 percentage point increase in the exposure index will lower the participation rate of immigrants living in the enclave by about 0.44 percent. Such an effect is moderate, because the average enclave index is about 1.5 percent whereas the participation rate ranges between 90 and 95 percent. In the lower panel of Table 4, I interact the enclave

\footnotetext{
${ }^{2}$ The estimates of the control variables are omitted, but they are available upon request.
} 
index with YSM groups; the marginal effects of enclave residence then vary over time for immigrants whose YSM is 11-20 years and less than 10 years. Before 1991, there are some positive effects of enclave residence on labour force participation, but the effect becomes mainly significantly negative in 1996 and 2001. For those who arrived in Canada 20 years before the observation year, the effect of enclave residence is always statistically insignificant.

Table 5 reports the regression results with models using a dummy to indicate residence in a large enclave. In the regressions without interaction, almost all the marginal effects of the enclave dummy are statistically insignificant, except for 1991 where they are significantly positive. When the enclave dummy is interacted with the YSM variables, the results are mostly insignificant, as shown in the lower panel of Table 5. In 1996 and 2001, the signs of the large enclaves are mainly negative and insignificant. In general, the small magnitude of the estimated effects and their lack of significance suggest that there is no evidence of a threshold effect, and that immigrants who live in large enclaves do not have a substantially higher labour force participation rate than those who live outside. Even the significant estimate in 1991 implies merely a 1.6 percentage point difference in participation rate between large and small enclaves.

\subsection{Regression Results of the Employment Model}

I then restrict my sample to labour force participants and use the indicator of immigrant employment status as the dependent variable in the probit regressions. It should be noted that since only labour force participants are sampled in this model, the regression results can be treated as an inverse effect on immigrants' unemployment rate. 
The estimated marginal effects of enclave variables are presented in Table 6 and 7. Similar to the participation model, estimates of the control variables in this model all have expected signs.

In the upper panel of Table 6, the marginal effects of the exposure index are positive and significant in all years except for 1981. To illustrate the effects, I use enclaves of Indian immigrants as an example. From Part B of Table 1, the enclave index for Indians in Vancouver is 4.71 percent while that in Hamilton is 1.28 percent in 2001. Given the estimated marginal effect of 0.183 in Table 6, an Indian immigrant in Vancouver is more likely to be employed than his compatriot in Hamilton by about 0.6 percentage point $[=(4.71 \%-1.28 \%) * 0.183]$. I then interact the exposure index with YSM groups and the marginal effects of the interacted terms are shown in the lower panel of the table. There seems to be inverse relationship between the effect of enclave index and immigrants' time in the host country. Since 1986, the marginal effect is significantly positive for the two more recent cohorts whose YSM is below 20, and is strongest for those who arrived in Canada within 10 years. For the earliest cohort, the effect turns statistically insignificant and small in magnitude. Estimates of the interacted variables suggest that it is the new immigrants who substantially benefit from enclave residence in terms of employment probability.

In Table 7, results from regressions where a large enclave dummy is used instead of a continuous enclave index show a similar pattern. The marginal effects of living in a large enclave are all positive and significant when the YSM-specific effect is not controlled for. However, when interacted with YSM groups, they diminish to zero for immigrants with more than 20 years in Canada, but remain significantly positive for those 
whose YSM is 10 and less. Take the 1996 Census for example: the estimated effect for the recent immigrants is 0.028 , which implies that those living in a large enclave have a higher employment probability than those in small enclaves by nearly 3 percentage points. The differential is substantial if viewed from the unemployment side. Since the enclave dummy provides a test for the threshold effect of living in large enclaves, it is not surprising to show stronger impact on immigrant employment probability than the continuous exposure index.

In summary, probit regression results have shown evidence of immigrant assimilation in labour market involvement because new immigrants have lower participation and employment probabilities than earlier cohorts. There is an inverse relationship between the magnitude of the effect of enclave residence on immigrant labour force activity and their years-since-migration: the later the arrival cohort, the stronger the impact. For immigrants whose YSM is over 20 years, there is almost no significant correlation between enclave and their labour force activity. However, for new immigrants who arrive within 10 years, enclave residence significantly lowers their labour force participation rate, but it significantly increases the participants' probability of being employed.

The causal relationship may seem doubtful when I regress the labour force activities on the contemporary enclave index. Considering the long time that it takes for an enclave to be established and developed while an immigrant's labour force activity is a relatively short-term status, it is reasonable to assume that the labour market outcome is affected by the ethnic enclaves rather than the inverse. However, it should be noted that in the long run, labour market performance of existing immigrants could influence the 
enclave size, or they could be both affected by some unobserved factors. These complications will be discussed in the following section.

\section{$5 \quad$ Endogeneity of Enclave Variables and IV Regressions}

Although the enclave size and intensity are not directly affected by the current labour market outcomes of immigrants, the probit regression results are not necessarily free from biases because immigrants may not choose residential location randomly. In addition to the easily accessible social network and low-cost ethnic goods, immigrants may also base their residential decisions on job opportunities and expected earnings in a city. The non-random geographic distribution of immigrants will have two complications on the probit regression analysis. First, it is possible that an immigrant who lacks the skills or ability specific to labour market success in the host-country tends to seek an enclave as an asylum, whereas an ambitious and self-motivated immigrant may be indifferent between living in an enclave and living outside. Since those unambitious and unmotivated enclave residents are less likely to participate or to be employed than those ambitious non-enclave residents, the estimated effect of enclave residence on immigrant labour force involvement may be negatively biased in a probit regression. Second, the size of an enclave may be endogenous to local labour market conditions. Suppose that immigrants are attracted to large cities, like Toronto and Vancouver, by the optimal economic conditions and substantial labour demand there. They will then build and develop ethnic enclaves in these cities. Although this process could take decades, the positive correlation between enclave size and job opportunities in an area would bias the probit estimates of enclave residence upwards. 
There is no unanimously accepted solution to this endogeneity problem. For example, Borjas (2000) argues that his potentially biased regression results provide a lower limit on the adverse impact of enclave residence on earning growth, and that the real effect could be even more negative. Edin et al. (2003) use the enclave size in the base year as an instrument for the size of the current enclave in which a refugee immigrant resides. Although a standard solution is still an open question, I will propose an instrumental variable (IV) approach to address the bias due to the endogeneity of enclaves.

An IV should be correlated with the endogenous enclave variables but uncorrelated with the error term of the main regression equation. An auxiliary equation including the IVs is regressed to predict values of enclave variable, and the fitted values are then used in the main regression function.

I choose the lagged enclave exposure index and mother tongue as the IVs for ethnic enclaves, because these variables are hypothesized not to affect the current labour market outcome of immigrants, yet they may play important roles when immigrants make residential decisions. The lagged enclave exposure index is often used as a determinant of present enclave intensity because it is documented (Altonji and Card 1991) that a large concentration of existing immigrants attracts new immigrants with the same cultural background. One reason may be that an existing enclave provides them with ethnic goods at a relatively low price and easy access to information (Zavodny 1997, Chowdhury and Pedace 2006 and Maré et al. 2008). Another reason could be the need of religious people for frequent communication and services at some religious institutions, as suggested by Breton (1964). It is economically wise for them to cluster around the place of worship 
that is built in an existing enclave. Because of the strong connection between ethnicity and religion groups, a church, mosque or temple will be the core of an ethnic community that attracts more immigrants with the same religion and hence increase the enclave size. ${ }^{3}$ Mother tongue, the other instrument, can be one major reason for many immigrants, particularly those who are not fluent in the official languages, to live in an ethnic enclave (Balakrishnan and Hou 1999). Since my sample is restricted to those from non-English or French speaking countries, heterogeneity in mother tongue is not likely correlated with immigrant labour market outcomes.

I report the IV regression results of participation and employment models using continuous and discrete enclave measures in Table 8 and 9 respectively. Because of the use of lagged variables, there is no regression for the 1981 Census.

In Table 8, the marginal effects of enclave index and large enclave dummy are insignificant on male immigrant labour force participation in Census 1986 and 1991. However, the effect turns significantly negative thereafter. For example, a 1 percentage point increase in enclave index lowers a male resident's participation rate by roughly 0.4 percentage point in 1996 and 2001. Meanwhile, estimates of enclave dummy in the lower panel indicate that the participation rate of an immigrant who lives in a large enclave is lower than someone outside by 3 percentage points. As expected, the negative effect of enclave is stronger than that estimated by a simple probit model.

Table 9 presents the IV regression results of male immigrant employment models. The marginal effects of enclave variables are all positive and significant, and their magnitudes are similar to those from probit regressions. This provides strong evidence

\footnotetext{
${ }^{3}$ I try to include religious status as an instrument variable in the regression, but it seems to be so highly collinear with the lagged enclave index that its coefficient is almost zero.
} 
that immigrants benefit from enclave residence in terms of employment probability. As shown in the lower panel, the marginal effect of the large enclave dummy varies between 1.3 and 3.2 percentage points over time, which can be treated as a big impact on unemployment. Considering the large number of new immigrants who choose to cluster in ethnic enclaves, they are the group who benefit most from enclave residence.

IV regression results confirm my findings with probit models. Immigrants living in ethnic enclaves tend to have lower participation rate in recent years, but they have a better chance of being employed once in the labour force.

\section{Conclusion}

An ethnic enclave can provide an immigrant with social networks and job opportunities that suit the human capital obtained from the source country, but living in an enclave will also hinder the immigrant's acquisition of host-country-specific skills. Therefore, the net effect of residing in an ethnic enclave on immigrant labour market performance is theoretically ambiguous. Many researchers attempt to disentangle the relationship between ethnic segregation and immigrant earnings, but no current study examines the effect of enclave residence on immigrant labour force activities using Canadian data. In this paper, I attempt to fill this gap in research through an empirical analysis on male immigrants using the 1981 - 2001 Canadian Censuses.

It is found that new immigrants who arrived in Canada after 1991 are more likely to cluster in large ethnic enclaves for a temporary or permanent source of social network, whereas old immigrant cohorts tend to live outside enclaves. With the inflow of skilled workers from Asian countries during the 1990s, the proportion of well-educated 
immigrants living in large enclaves has substantially increased.

Probit and IV regressions show that enclave variables that measure the intensity of ethnic clustering are negatively correlated with the labour force participation rate in the late 1990s, but the magnitude is moderate. By interacting immigrants' years-sincemigration with enclave variables, I find that the impact on new immigrants' participation rate is significantly negative. This finding can be explained by immigrants' human capital investment and welfare participation. Aydemir's (2009) recent study shows that refugees living in enclaves are more likely to invest in language or professional training than those living outside. One possible reason may be the relatively low costs of providing ethnicity-specific training services in an enclave. When there are a large number of immigrants who do not speak the official languages fluently, and only a limited number of positions offered by ethnic companies, the need for language training is then increased for those who want to work in non-ethnic companies. If the lower participation rate is due to immigrants' investment in human capital, it is then not necessary to worry about the negative effect of enclave residence. Additionally, through ethnic networks, immigrants who are not proficient in English or French can easily get access to information about social welfare. Bertrand et al. (2000) find that access to a same-language network is positively related to welfare participation. Eligibility for social assistance can be treated as an increase in non-labour income and therefore as a disincentive of labour force participation.

In terms of the likelihood of being employed, immigrants, specifically the most recent arrival cohorts, actually benefit from living in ethnic enclaves. All the probit regression results suggest that immigrants in a large enclave have a higher employment 
probability than those living outside by 1 to 2 percentage points, which can be interpreted as a substantial impact on the unemployment rate. Considering the aforementioned human capital investment by enclave residents, the higher employment probability may be the reward to their newly acquired Canadian education or training. Moreover, the positive effect of enclave residence on employment may be explained by job opportunities in ethnic companies. Immigrants who want to work but lack Canadian-specific skills may choose to work in ethnic firms. When the within-ethnicity competition turns keen with the increasing size of enclave, the average wage is driven down, and those not employed may then undertake training or education and become non-participants. In addition, labour market information provided by the ethnic network may help new immigrants obtain jobs in non-ethnic firms too. Balakrishnan and Hou (1999) argue that immigrants become more mobile between place of work and residence because of the growing urbanization. It is more and more likely for immigrants to live in enclaves to enjoy the low-cost ethnic goods and work outside ethnic segregation to earn higher wages.

In summary, enclave residence slightly reduces the immigrant labour force participation rate, but increases their probability of employment. Both impacts are stronger for new immigrants than old arrival cohorts. For the majority of immigrants, there is no clear evidence that their labour force involvement is hurt by enclave residence. This partially address the question raised by Borjas (2000) and Warman (2007) as to why immigrants still choose to live in ethnic enclaves in spite of its negative impact on wage growth: the benefit of low training costs or job opportunities offered by enclaves may outweigh the loss in wages. Based on this, policies on immigrant labour market 
assimilation should rather focus on raising wages than on improving employment opportunities. 


\section{References}

Altonji, Joseph G. and David Card (1991) "The Effects of Immigration on the Labor Market Outcomes of Less-Skilled Natives.” In Immigration, Trade, and the Labor Market, edited by J. M. Abowd and R. B. Freeman. University of Chicago Press.

Aydemir, Abdurrahman (2009) "Ethnic Enclaves and Human Capital Investments: Evidence from a Natural Experiment," Paper presented at the Economics of Immigration: Children of Immigrants \& Temporary Migration, May 11-12, 2009, Vancouver BC.

Baker, Michael, and Dwayne Benjamin (1994) “The Performance of Immigrants in the Canadian Labor Market,” Journal of Labor Economics, 12(3), 369-405.

Balakrishnan, T.R., and Feng Hou (1999) "Socioeconomic Integration and Spatial Residential Patterns of Immigrant Groups in Canada,” Population Research and Policy Review, 18(3), 201-217.

Bartel, Ann (1989) “Where Do the New Immigrants Live?” Journal of Labor Economics, 7(4), 371-391

Bertrand, Marianne, Erzo F.P. Luttmer, and Sendhil Mullianathan (2000) "Network Effects and Welfare Cultures,” Quarterly Journal of Economics, 115(3), 1019-1055.

Bloom, David E., Gilles Grenier, and Morely Gunderson (1995) “The Changing Labour Market Position of Canadian Immigrants," Canadian Journal of Economics, 28(4b), 987-1005.

Borjas, George J. (1986) “The Self-employment Experience of Immigrants,” Journal of Human Resources, 21(4), 485-506.

_ (2000) "Ethnic Enclaves and Assimilation," Swedish Economic Policy Review, 7, 89-122.

Breton, Raymond (1964) "Institutional Completeness of Ethnic Communities and Personal Relations to Immigrants,” American Journal of Sociology, 70(2), 193-205.

Chiswick, Barry R., and Paul W. Miller (2002) "Do Enclaves Matter in Immigrant Adjustment?” Discussion Paper No. 449, Institute for the Study of Labor (IZA).

Chowdhury, Mussaddeq and Roberto Pedace (2007) "Ethnic Enclaves and Labor Markets: An Analysis of Immigrant Outcomes in California," Contemporary Economic Policy 25(2), 238-249.

Clark, Kenneth, and Stephen Drinkwater (2002) "Enclaves, Neighbourhood Effects and Employment Outcomes: Ethnic Minorities in England and Wales," Journal of Population Economics, 15(1), 5-29. 
Edin, Peter-Anders, Peter Fredriksson, and Olof Aslund (2003) "Ethnic Enclaves and the Economic Success of Immigrants - Evidence from A Natural Experiment," Quarterly Journal of Economics, 118(1), 329-357.

Frenette, Marc, and Rene Morisette (2003) "Will They Ever Converge? Earnings of Immigrant and Canadian-born Workers over the Last Two Decades," Analytical Studies Branch Research Paper Series, No. 215, Statistics Canada, Ottawa.

Goel, Deepti and Kevin Lang (2009) "The Role of Social Ties in the Job Search of Recent Immigrants,” Working Papers No. 5, clsrn_admin-2009-12, CLSRN, the Department of Economics, University of British Columbia.

Gray, David, Jeffrey Mills and Sourushe Zandvakili (2003) "Immigration, Assimilation and Inequality of Income Distribution in Canada," University of Cincinnati, Department of Economics, Economics Working Papers Series, 2003-01.

Hou, Feng, and Garnett Picot (2003) "Visible-Minority Neighbourhood Enclaves Labour Market Outcomes of Immigrants," in Canadian Immigration Policy for the 21st Century, ed. Charles M. Beach, Alan G. Green, and Jeffrey G. Reitz (Kingston, ON: John Deutsch Institute).

Hum, Derek, and Wayne Simpson (2000) "Closing the Wage Gap: Economic Assimilation of Canadian Immigrants Reconsidered," Journal of International Migration and Integration, 1(4), 427-441.

Lazear, Edward P. (1999) “Culture and Language,” Journal of Political Economy, 107(6), 95-126.

Maré, Dave, Steven Stillman and Melanie Morten (2008) "Settlement Patterns and the Geographic Mobility of Recent Migrants to New Zealand," Economic Impacts of Immigration Working Paper Series, the Department of Labour, New Zealand, http://www.dol.govt.nz/PDFs/settlement-patterns.pdf.

Warman, Casey (2007) "Ethnic Enclaves and Immigrant Earnings Growth," Canadian Journal of Economics, 40(2), 401-422.

Zavodny, Madeline (1997) "Welfare and the Locational Choices of New Immigrants," Economic Review, Federal Reserve Bank of Dallas, issue Q II, 2-10. 
Figure 1

Male Immigrant-Native Differences in Labour Force Participation Rate by Birth Cohort over Age, Census 1981 - 2001

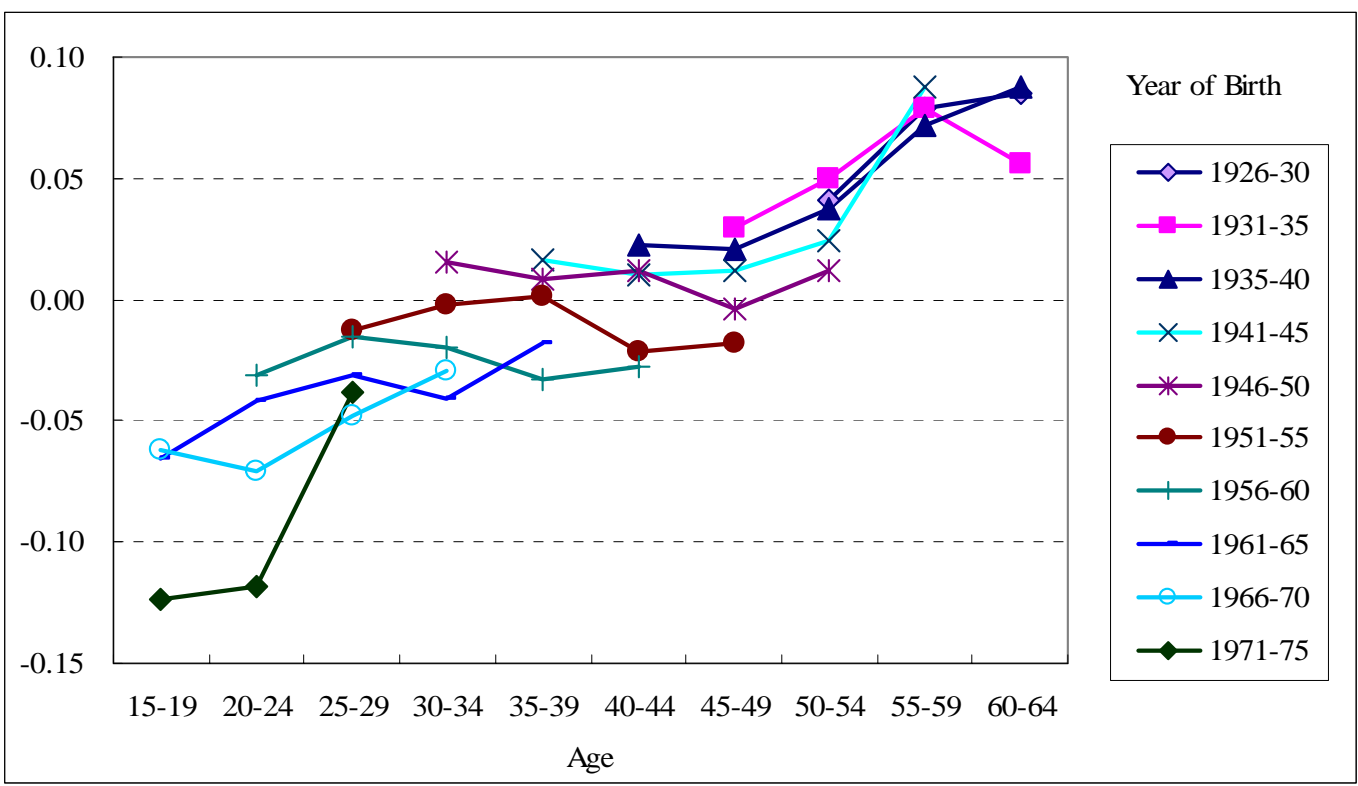

NOTES: The sample is restricted to male natives and immigrants aged 25-54.

Figure 2

Male Immigrant-Native Differences in Employment Rate by Birth Cohort over Age, Census 1981 - 2001

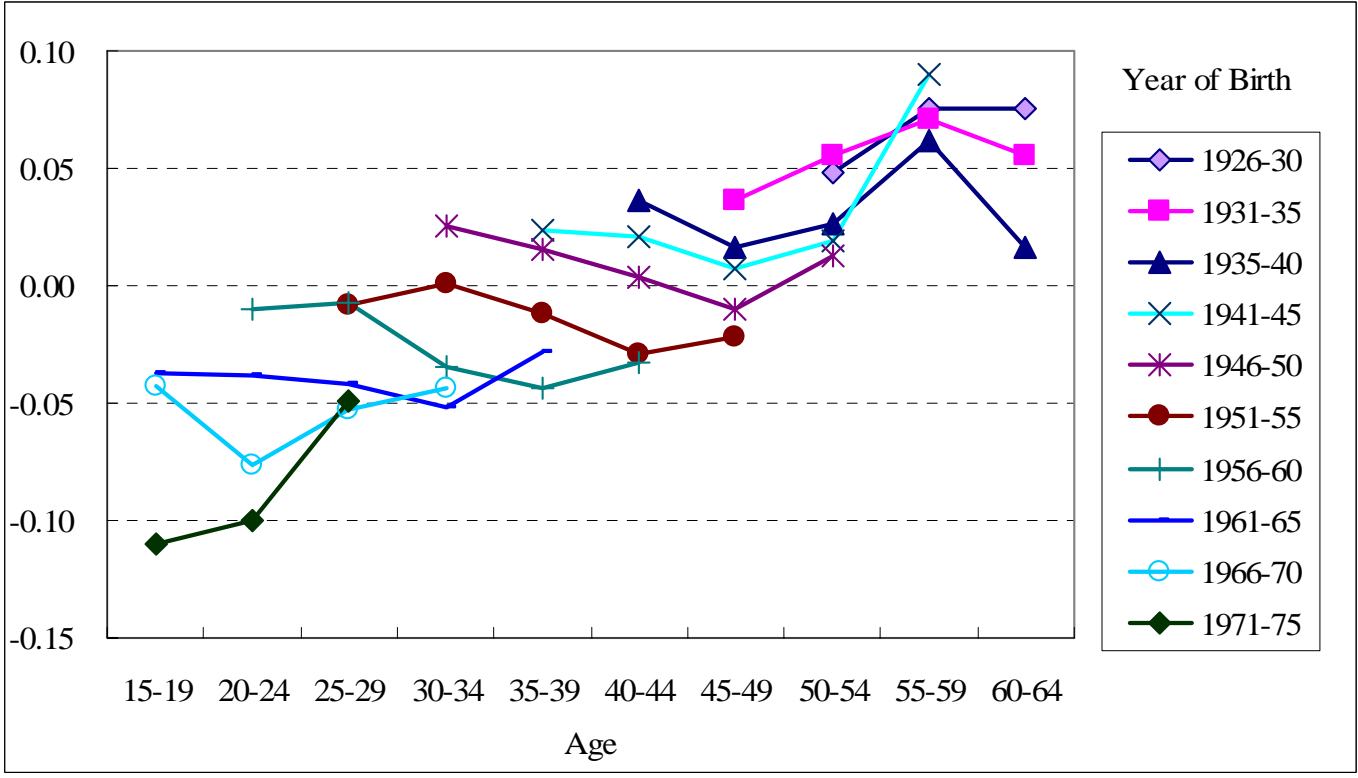

NOTES: Same as Figure 1. 
Figure 3

Male Immigrant-Native Differences in Labour Force Participation Rate by Immigrant Arrival Cohort, Census 1981 - 2001

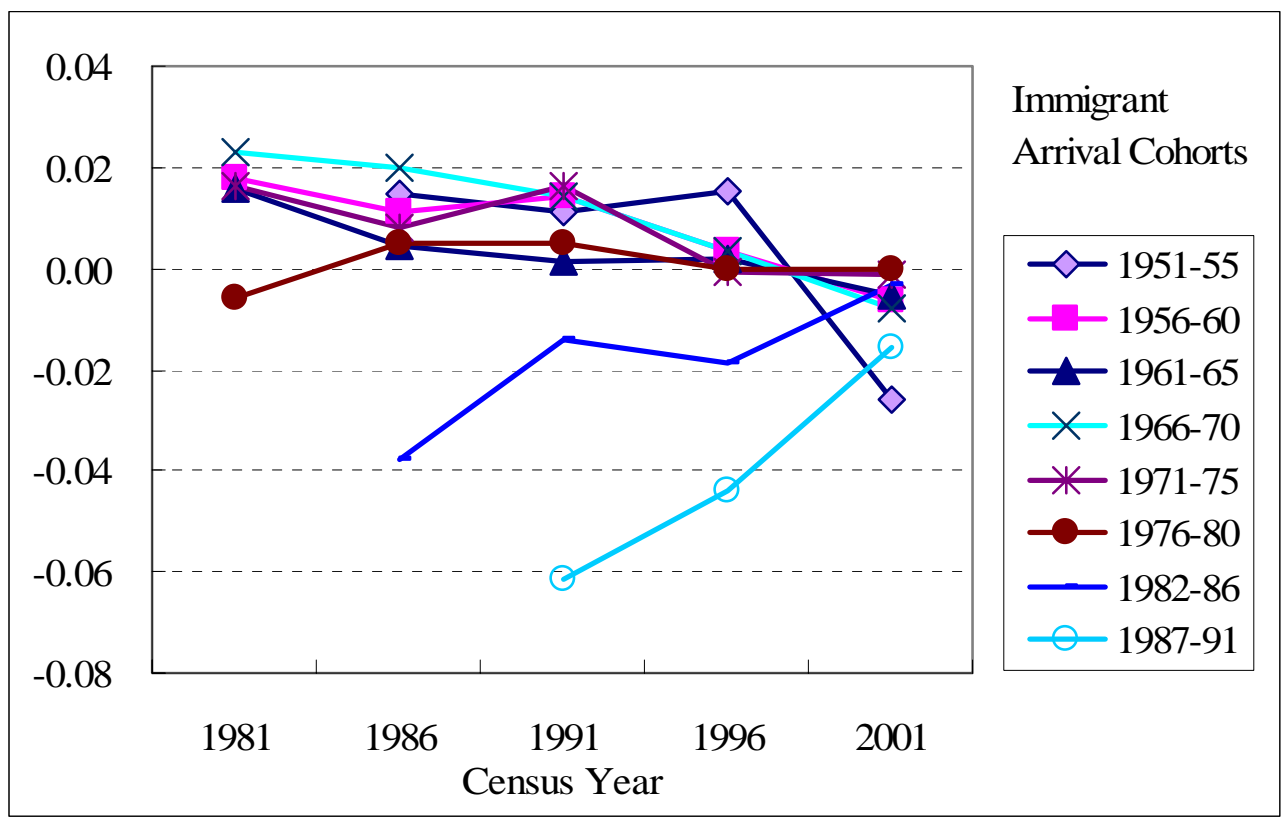

NOTES: Same as Figure 1.

Figure 4

Male Immigrant-Native Differences in Employment Rate by Immigrant Arrival Cohort, Census $1981-2001$

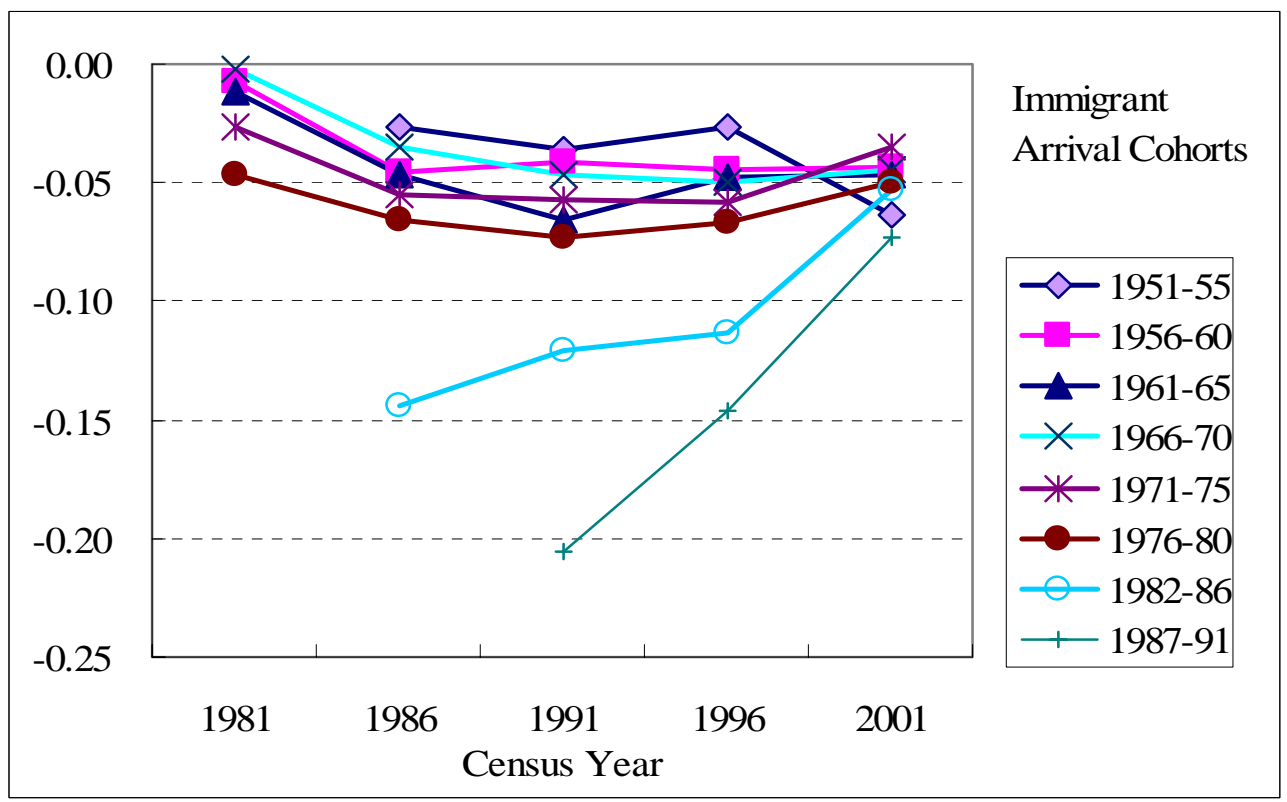

NOTES: Same as Figure 1. 
Table 1

Enclaves with the Highest Exposure Indices by Ethnicity and CMA, Census 2001

\begin{tabular}{|c|c|c|c|c|c|c|c|c|c|c|}
\hline & German & Polish & Portuguese & Italian & Chinese & Indian & Filipino & Arab & Korean & Jamaican \\
\hline Montreal & - & - & - & $2.09 \%$ & $1.15 \%$ & $1.05 \%$ & - & $1.95 \%$ & - & - \\
\hline Ottawa - Hull & - & - & - & - & $1.94 \%$ & $1.24 \%$ & - & $1.70 \%$ & - & - \\
\hline Toronto & - & $1.24 \%$ & $1.88 \%$ & $3.07 \%$ & $6.58 \%$ & $6.81 \%$ & $1.97 \%$ & - & - & $1.51 \%$ \\
\hline Hamilton & - & $1.33 \%$ & - & $2.48 \%$ & - & $1.28 \%$ & - & - & - & - \\
\hline St. Catharines \& Niagara Falls & - & - & - & $3.10 \%$ & - & - & - & - & - & - \\
\hline Kitchener & $1.69 \%$ & - & $1.91 \%$ & - & - & $1.78 \%$ & - & - & - & - \\
\hline London & - & $1.27 \%$ & $1.24 \%$ & - & - & - & - & - & - & - \\
\hline Windsor & - & - & - & $3.06 \%$ & - & - & - & $2.53 \%$ & - & - \\
\hline Winnipeg & $1.30 \%$ & - & - & - & - & $1.10 \%$ & $2.74 \%$ & - & - & - \\
\hline Calgary & - & - & - & - & $3.43 \%$ & $2.48 \%$ & $1.08 \%$ & - & - & - \\
\hline Edmonton & - & - & - & - & $2.67 \%$ & $2.00 \%$ & - & - & - & - \\
\hline Vancouver & - & - & - & - & $12.98 \%$ & $4.71 \%$ & $1.97 \%$ & - & $1.06 \%$ & - \\
\hline Victoria & - & - & - & - & $1.84 \%$ & - & - & - & - & - \\
\hline
\end{tabular}

NOTES: Enclave exposure index = number of immigrants with an ethnicity in a city / total population of the city 
Table 2

Distribution of Enclave Residence for Male Immigrants by Socio-Economic Characteristics, Census 1981 - 2001

\begin{tabular}{|c|c|c|c|c|c|c|c|c|c|c|c|c|c|c|c|}
\hline \multirow[b]{2}{*}{ Enclave Index Percentiles } & \multicolumn{3}{|c|}{$1981(n=14,118)$} & \multicolumn{3}{|c|}{$1986(n=14,734)$} & \multicolumn{3}{|c|}{$1991(n=24,936)$} & \multicolumn{3}{|c|}{$1996(n=28,351)$} & \multicolumn{3}{|c|}{$2001(n=30,309)$} \\
\hline & Small & Medium & Large & Small & Medium & Large & Small & Medium & Large & Small & Medium & Large & Small & Medium & Large \\
\hline YSM > 20 & 0.37 & 0.37 & 0.26 & 0.37 & 0.34 & 0.28 & 0.34 & 0.34 & 0.33 & 0.37 & 0.34 & 0.30 & 0.39 & 0.33 & 0.29 \\
\hline YSM 11-20 & 0.28 & 0.40 & 0.32 & 0.30 & 0.34 & 0.35 & 0.32 & 0.34 & 0.35 & 0.34 & 0.34 & 0.31 & 0.36 & 0.34 & 0.30 \\
\hline $\mathrm{YSM} \leq 10$ & 0.22 & 0.42 & 0.36 & 0.32 & 0.38 & 0.30 & 0.33 & 0.34 & 0.33 & 0.27 & 0.37 & 0.37 & 0.27 & 0.34 & 0.39 \\
\hline Less than High School & 0.29 & 0.37 & 0.34 & 0.31 & 0.29 & 0.40 & 0.33 & 0.31 & 0.36 & 0.34 & 0.32 & 0.34 & 0.37 & 0.30 & 0.33 \\
\hline High School Graduates & 0.32 & 0.41 & 0.28 & 0.35 & 0.37 & 0.28 & 0.34 & 0.35 & 0.32 & 0.33 & 0.36 & 0.31 & 0.34 & 0.34 & 0.32 \\
\hline Some Postsecondary & 0.31 & 0.41 & 0.28 & 0.34 & 0.41 & 0.25 & 0.34 & 0.35 & 0.31 & 0.33 & 0.35 & 0.32 & 0.36 & 0.35 & 0.29 \\
\hline Bachelor's Degree & 0.24 & 0.42 & 0.34 & 0.33 & 0.39 & 0.29 & 0.29 & 0.33 & 0.38 & 0.26 & 0.37 & 0.37 & 0.27 & 0.33 & 0.40 \\
\hline Postgraduate & 0.30 & 0.44 & 0.25 & 0.41 & 0.39 & 0.21 & 0.34 & 0.38 & 0.28 & 0.32 & 0.37 & 0.30 & 0.30 & 0.35 & 0.34 \\
\hline $\begin{array}{l}\text { Mother Tongue is English or } \\
\text { French }\end{array}$ & 0.29 & 0.45 & 0.25 & 0.31 & 0.34 & 0.35 & 0.31 & 0.28 & 0.41 & 0.29 & 0.28 & 0.42 & 0.30 & 0.43 & 0.27 \\
\hline $\begin{array}{l}\text { Knowledge of English or French } \\
\text { but Other Mother Tongue }\end{array}$ & 0.31 & 0.38 & 0.31 & 0.35 & 0.36 & 0.30 & 0.34 & 0.35 & 0.31 & 0.33 & 0.37 & 0.30 & 0.34 & 0.32 & 0.34 \\
\hline No Official Language & 0.19 & 0.41 & 0.40 & 0.19 & 0.27 & 0.54 & 0.25 & 0.36 & 0.40 & 0.22 & 0.31 & 0.47 & 0.22 & 0.22 & 0.55 \\
\hline
\end{tabular}

NOTES: "Small" means enclaves with an exposure index at the lowest $1 / 3$, while "Large" enclaves refer to those at the top $1 / 3$. Value of each cell $=$ immigrants of a socio-economic group that live in an enclave percentile range / total immigrants of the group. The sample is restricted to males aged 25-54 with positive wages living in Ontario, Quebec, Manitoba, Saskatchewan, Alberta, British Columbia. 
Table 3

Sample Means by Enclave Residence and Immigration Status for Males

\begin{tabular}{|c|c|c|c|c|c|}
\hline Census 1981 & $\begin{array}{l}\text { Immigrants in } \\
\text { Small } \\
\text { Enclaves }\end{array}$ & $\begin{array}{l}\text { Immigrants in } \\
\text { Medium } \\
\text { Enclaves }\end{array}$ & $\begin{array}{l}\text { Immigrants in } \\
\text { Large } \\
\text { Enclaves }\end{array}$ & $\begin{array}{l}\text { English / } \\
\text { French } \\
\text { Immigrants }\end{array}$ & Natives \\
\hline Employed & 0.92 & 0.92 & 0.93 & 0.94 & 0.90 \\
\hline Unemployed & 0.03 & 0.03 & 0.03 & 0.03 & 0.04 \\
\hline Not in Labour Force & 0.05 & 0.05 & 0.04 & 0.03 & 0.06 \\
\hline Work in the same CSD & 0.54 & 0.49 & 0.41 & 0.46 & 0.51 \\
\hline Annual Wages (\$) & 32,041 & 31,570 & 30,680 & 38,891 & 33,244 \\
\hline Annual Earnings (\$) & 36,213 & 35,490 & 33,026 & 42,001 & 36,690 \\
\hline Age & 39.95 & 39.13 & 38.61 & 39.32 & 37.15 \\
\hline Married & 0.82 & 0.83 & 0.85 & 0.81 & 0.77 \\
\hline Visible Minority & 0.00 & 0.00 & 0.00 & 0.00 & 0.00 \\
\hline Dwelling Owned & 0.74 & 0.70 & 0.73 & 0.67 & 0.69 \\
\hline Same CSD in 5 years & 0.73 & 0.70 & 0.74 & 0.64 & 0.73 \\
\hline Observation & 4,214 & 5,574 & 4,330 & 5,877 & 68,063 \\
\hline Census 1986 & $\begin{array}{l}\text { Immigrants in } \\
\text { Small } \\
\text { Enclaves }\end{array}$ & $\begin{array}{l}\text { Immigrants in } \\
\text { Medium } \\
\text { Enclaves }\end{array}$ & $\begin{array}{l}\text { Immigrants in } \\
\text { Large } \\
\text { Enclaves }\end{array}$ & $\begin{array}{l}\text { English / } \\
\text { French } \\
\text { Immigrants }\end{array}$ & Natives \\
\hline Employed & 0.87 & 0.87 & 0.90 & 0.91 & 0.87 \\
\hline Unemployed & 0.07 & 0.07 & 0.05 & 0.05 & 0.07 \\
\hline Not in Labour Force & 0.05 & 0.06 & 0.06 & 0.04 & 0.06 \\
\hline Work in the same CSD & N/A & N/A & N/A & N/A & N/A \\
\hline Annual Wages (\$) & 29,529 & 29,201 & 28,740 & 38,163 & 30,889 \\
\hline Annual Earnings (\$) & 32,821 & 32,251 & 31,233 & 41,227 & 33,661 \\
\hline Age & 40.29 & 39.89 & 39.32 & 40.02 & 36.90 \\
\hline Married & 0.82 & 0.81 & 0.83 & 0.79 & 0.74 \\
\hline Visible Minority & 0.33 & 0.33 & 0.50 & 0.09 & 0.01 \\
\hline Dwelling Owned & 0.70 & 0.65 & 0.77 & 0.69 & 0.67 \\
\hline Same CSD in 5 years & 0.75 & 0.74 & 0.80 & 0.72 & 0.77 \\
\hline Observation & 4,932 & 5,190 & 4,612 & 5,385 & 76,691 \\
\hline Census 1991 & $\begin{array}{c}\text { Immigrants in } \\
\text { Small } \\
\text { Enclaves }\end{array}$ & $\begin{array}{l}\text { Immigrants in } \\
\text { Medium } \\
\text { Enclaves }\end{array}$ & $\begin{array}{c}\text { Immigrants in } \\
\text { Large } \\
\text { Enclaves } \\
\end{array}$ & $\begin{array}{l}\text { English / } \\
\text { French } \\
\text { Immigrants } \\
\end{array}$ & Natives \\
\hline Employed & 0.84 & 0.83 & 0.86 & 0.90 & 0.86 \\
\hline Unemployed & 0.09 & 0.10 & 0.08 & 0.06 & 0.08 \\
\hline Not in Labour Force & 0.07 & 0.07 & 0.06 & 0.04 & 0.06 \\
\hline Work in the same CSD & 0.56 & 0.48 & 0.40 & 0.45 & 0.50 \\
\hline Annual Wages (\$) & 27,450 & 28,201 & 29,270 & 38,201 & 31,945 \\
\hline Annual Earnings (\$) & 30,586 & 31,215 & 31,638 & 41,540 & 34,817 \\
\hline Age & 39.72 & 40.01 & 39.35 & 40.40 & 37.45 \\
\hline Married & 0.78 & 0.79 & 0.81 & 0.78 & 0.72 \\
\hline Visible Minority & 0.44 & 0.40 & 0.67 & 0.17 & 0.01 \\
\hline Dwelling Owned & 0.61 & 0.64 & 0.76 & 0.69 & 0.69 \\
\hline Same CSD in 5 years & 0.64 & 0.66 & 0.65 & 0.67 & 0.73 \\
\hline Observation & 8,227 & 8,433 & 8,276 & 8,911 & 129,191 \\
\hline
\end{tabular}


Table 3 (concluded)

Sample Means by Enclave Residence and Immigration Status for Males

\begin{tabular}{|c|c|c|c|c|c|}
\hline Census 1996 & $\begin{array}{l}\text { Immigrants in } \\
\text { Small } \\
\text { Enclaves }\end{array}$ & $\begin{array}{l}\text { Immigrants in } \\
\text { Medium } \\
\text { Enclaves }\end{array}$ & $\begin{array}{c}\text { Immigrants in } \\
\text { Large } \\
\text { Enclaves }\end{array}$ & $\begin{array}{l}\text { English / } \\
\text { French } \\
\text { Immigrants }\end{array}$ & Natives \\
\hline Employed & 0.81 & 0.79 & 0.79 & 0.89 & 0.85 \\
\hline Unemployed & 0.09 & 0.10 & 0.07 & 0.05 & 0.07 \\
\hline Not in Labour Force & 0.10 & 0.12 & 0.13 & 0.06 & 0.08 \\
\hline Work in the same CSD & 0.47 & 0.41 & 0.36 & 0.43 & 0.44 \\
\hline Annual Wages (\$) & 24,392 & 23,017 & 23,186 & 35,722 & 29,776 \\
\hline Annual Earnings (\$) & 26,942 & 25,205 & 25,245 & 38,950 & 32,272 \\
\hline Age & 40.48 & 39.78 & 39.61 & 41.48 & 38.59 \\
\hline Married & 0.76 & 0.76 & 0.77 & 0.75 & 0.69 \\
\hline Visible Minority & 0.43 & 0.51 & 0.83 & 0.09 & 0.01 \\
\hline Dwelling Owned & 0.60 & 0.56 & 0.71 & 0.70 & 0.69 \\
\hline Same CSD in 5 years & 0.72 & 0.72 & 0.67 & 0.72 & 0.77 \\
\hline Observation & 9,081 & 9,950 & 9,320 & 6,822 & 126,972 \\
\hline Census 2001 & $\begin{array}{l}\text { Immigrants in } \\
\text { Small } \\
\text { Enclaves }\end{array}$ & $\begin{array}{l}\text { Immigrants in } \\
\text { Medium } \\
\text { Enclaves }\end{array}$ & $\begin{array}{l}\text { Immigrants in } \\
\text { Large } \\
\text { Enclaves }\end{array}$ & $\begin{array}{l}\text { English / } \\
\text { French } \\
\text { Immigrants }\end{array}$ & Natives \\
\hline Employed & 0.83 & 0.83 & 0.83 & 0.88 & 0.87 \\
\hline Unemployed & 0.07 & 0.06 & 0.05 & 0.04 & 0.05 \\
\hline Not in Labour Force & 0.11 & 0.10 & 0.12 & 0.08 & 0.08 \\
\hline Work in the same CSD & 0.51 & 0.50 & 0.49 & 0.49 & 0.47 \\
\hline Annual Wages (\$) & 26,310 & 27,014 & 26,481 & 37,054 & 33,086 \\
\hline Annual Earnings (\$) & 29,238 & 29,448 & 28,738 & 40,648 & 35,769 \\
\hline Age & 41.01 & 40.35 & 40.44 & 41.76 & 39.56 \\
\hline Married & 0.75 & 0.75 & 0.81 & 0.73 & 0.68 \\
\hline Visible Minority & 0.51 & 0.59 & 0.85 & 0.14 & 0.02 \\
\hline Dwelling Owned & 0.60 & 0.57 & 0.71 & 0.70 & 0.71 \\
\hline Same CSD in 5 years & 0.73 & 0.71 & 0.69 & 0.74 & 0.79 \\
\hline Observation & 10,105 & 10,130 & 10,074 & 6,082 & 126,726 \\
\hline
\end{tabular}

NOTES: Each cell presents the weighted average of an enclave group. The sample is restricted to males aged 25-54 with positive wages living in Ontario, Quebec, Manitoba, Saskatchewan, Alberta, British Columbia. 
Table 4

\section{Probit Regressions of Male Immigrant Labour Force Participation: Marginal Effects of Enclave Exposure Index}

\begin{tabular}{|c|c|c|c|c|c|}
\hline Census & $\begin{array}{c}(1) \\
1981 \\
\end{array}$ & $\begin{array}{c}(2) \\
1986 \\
\end{array}$ & $\begin{array}{c}(3) \\
1991 \\
\end{array}$ & $\begin{array}{c}(4) \\
1996 \\
\end{array}$ & $\begin{array}{c}(5) \\
2001 \\
\end{array}$ \\
\hline \multicolumn{6}{|l|}{ Regressions with No Interaction } \\
\hline Enclave Index & $\begin{array}{c}0.081 \\
(0.068)\end{array}$ & $\begin{array}{c}0.092 \\
(0.114)\end{array}$ & $\begin{array}{c}0.149 \\
(0.155)\end{array}$ & $\begin{array}{c}-0.436^{* * *} \\
(0.090)\end{array}$ & $\begin{array}{c}-0.346^{* * * *} \\
(0.128)\end{array}$ \\
\hline Pseudo $\mathrm{R}^{2}$ & 0.05 & 0.05 & 0.06 & 0.06 & 0.05 \\
\hline \multicolumn{6}{|c|}{ Regressions with Enclave Index Interacted with YSM Group } \\
\hline Enclave Index * YSM > 20 & $\begin{array}{l}-0.048 \\
(0.131)\end{array}$ & $\begin{array}{l}-0.051 \\
(0.202)\end{array}$ & $\begin{array}{c}0.237 \\
(0.185)\end{array}$ & $\begin{array}{l}-0.000 \\
(0.270)\end{array}$ & $\begin{array}{c}0.015 \\
(0.120)\end{array}$ \\
\hline Enclave Index * YSM 11-20 & $\begin{array}{c}0.156 \\
(0.103)\end{array}$ & $\begin{array}{l}-0.123 \\
(0.114)\end{array}$ & $\begin{array}{c}0.496 * * * \\
(0.134)\end{array}$ & $\begin{array}{c}-0.085 \\
(0.124)\end{array}$ & $\begin{array}{c}-0.166^{* *} \\
(0.081)\end{array}$ \\
\hline Enclave Index * YSM $<10$ & $\begin{array}{c}0.122 \\
(0.107)\end{array}$ & $\begin{array}{c}0.632 * * * \\
(0.175)\end{array}$ & $\begin{array}{l}-0.069 \\
(0.275)\end{array}$ & $\begin{array}{c}-0.653^{* * *} \\
(0.158)\end{array}$ & $\begin{array}{c}-0.528^{* *} \\
(0.211)\end{array}$ \\
\hline $\begin{array}{l}\text { Pseudo } \mathrm{R}^{2} \\
\text { Observations }\end{array}$ & $\begin{array}{c}0.05 \\
14,893\end{array}$ & $\begin{array}{c}0.05 \\
15,348\end{array}$ & $\begin{array}{c}0.06 \\
27,496\end{array}$ & $\begin{array}{c}0.06 \\
29,709\end{array}$ & $\begin{array}{c}0.05 \\
30,997\end{array}$ \\
\hline
\end{tabular}

NOTES: Robust standard errors are in parentheses. Significance levels are indicated by $*$ for $10 \%, * *$ for $5 \%$, and $* * *$ for $1 \%$. The dependent variable is the dummy indicating whether an individual participates in the labour force (employed or unemployed). Regressions control for years-since-migration, age group, educational attainment, knowledge of official languages, marital status, visible minority status and province of residence. The sample is restricted to males aged 25-54 living in Ontario, Quebec, Manitoba, Saskatchewan, Alberta, British Columbia. 
Table 5

Probit Regressions of Male Immigrant Labour Force Participation: Marginal Effects of Large Enclave Dummy

\begin{tabular}{|c|c|c|c|c|c|}
\hline Census & $\begin{array}{c}(1) \\
1981 \\
\end{array}$ & $\begin{array}{c}(2) \\
1986 \\
\end{array}$ & $\begin{array}{c}(3) \\
1991\end{array}$ & $\begin{array}{c}(4) \\
1996 \\
\end{array}$ & $\begin{array}{c}(5) \\
2001\end{array}$ \\
\hline \multicolumn{6}{|l|}{$\underline{\text { Regressions with No Interaction }}$} \\
\hline Large Enclave Dummy & $\begin{array}{c}0.003 \\
(0.004)\end{array}$ & $\begin{array}{c}0.004 \\
(0.004)\end{array}$ & $\begin{array}{c}0.011^{* *} \\
(0.005)\end{array}$ & $\begin{array}{l}-0.011 \\
(0.008)\end{array}$ & $\begin{array}{l}-0.008 \\
(0.008)\end{array}$ \\
\hline Pseudo $\mathrm{R}^{2}$ & 0.05 & 0.05 & 0.06 & 0.05 & 0.05 \\
\hline \multicolumn{6}{|c|}{ Regressions with Large Enclave Dummy Interacted with YSM Group } \\
\hline Large Enclave * YSM>20 & $\begin{array}{l}-0.000 \\
(0.006)\end{array}$ & $\begin{array}{l}-0.002 \\
(0.007)\end{array}$ & $\begin{array}{c}0.007 \\
(0.005)\end{array}$ & $\begin{array}{l}-0.018 * \\
(0.010)\end{array}$ & $\begin{array}{r}0.003 \\
(0.007)\end{array}$ \\
\hline Large Enclave * YSM 11-20 & $\begin{array}{l}0.008 * \\
(0.005)\end{array}$ & $\begin{array}{c}-0.000 \\
(0.005)\end{array}$ & $\begin{array}{c}0.016 * * * \\
(0.005)\end{array}$ & $\begin{array}{l}-0.010 \\
(0.009)\end{array}$ & $\begin{array}{l}-0.010 \\
(0.007)\end{array}$ \\
\hline Large Enclave * YSM $<10$ & $\begin{array}{c}0.002 \\
(0.008)\end{array}$ & $\begin{array}{c}0.017 * * * \\
(0.005)\end{array}$ & $\begin{array}{c}0.011 \\
(0.009)\end{array}$ & $\begin{array}{l}-0.007 \\
(0.017)\end{array}$ & $\begin{array}{l}-0.015 \\
(0.019)\end{array}$ \\
\hline $\begin{array}{l}\text { Pseudo } \mathrm{R}^{2} \\
\text { Observations }\end{array}$ & $\begin{array}{c}0.05 \\
14,893\end{array}$ & $\begin{array}{c}0.05 \\
15,348\end{array}$ & $\begin{array}{c}0.06 \\
27,496\end{array}$ & $\begin{array}{c}0.05 \\
29,709\end{array}$ & $\begin{array}{c}0.05 \\
30,997\end{array}$ \\
\hline
\end{tabular}

NOTES: Same as Table 4 
Table 6

Probit Regressions of Male Immigrant Employment: Marginal Effects of Enclave Exposure Index

\begin{tabular}{|c|c|c|c|c|c|}
\hline Census & $\begin{array}{c}(1) \\
1981 \\
\end{array}$ & $\begin{array}{c}(2) \\
1986 \\
\end{array}$ & $\begin{array}{c}(3) \\
1991 \\
\end{array}$ & $\begin{array}{c}(4) \\
1996 \\
\end{array}$ & $\begin{array}{c}(5) \\
2001 \\
\end{array}$ \\
\hline \multicolumn{6}{|c|}{ Regressions with No Interaction } \\
\hline Enclave Index & $\begin{array}{c}0.090 \\
(0.055)\end{array}$ & $\begin{array}{c}0.451 * * * \\
(0.151)\end{array}$ & $\begin{array}{c}0.596 * * * \\
(0.168)\end{array}$ & $\begin{array}{c}0.375^{* * *} \\
(0.104)\end{array}$ & $\begin{array}{c}0.183^{* * *} \\
(0.056)\end{array}$ \\
\hline Pseudo $\mathrm{R}^{2}$ & 0.05 & 0.06 & 0.05 & 0.06 & 0.05 \\
\hline \multicolumn{6}{|c|}{ Regressions with Enclave Index Interacted with YSM Group } \\
\hline Enclave Index * YSM $>20$ & $\begin{array}{l}-0.012 \\
(0.132)\end{array}$ & $\begin{array}{c}0.298 \\
(0.247)\end{array}$ & $\begin{array}{c}0.204 \\
(0.246)\end{array}$ & $\begin{array}{c}0.136 \\
(0.151)\end{array}$ & $\begin{array}{c}0.063 \\
(0.078)\end{array}$ \\
\hline Enclave Index * YSM 11-20 & $\begin{array}{c}0.111 \\
(0.133)\end{array}$ & $\begin{array}{c}0.428 * * \\
(0.187)\end{array}$ & $\begin{array}{l}0.419 * \\
(0.236)\end{array}$ & $\begin{array}{c}0.409 * * * \\
(0.115)\end{array}$ & $\begin{array}{c}0.178^{* * *} \\
(0.064)\end{array}$ \\
\hline Enclave Index * YSM $<10$ & $\begin{array}{c}0.135 \\
(0.095)\end{array}$ & $\begin{array}{c}0.659 * * * \\
(0.250)\end{array}$ & $\begin{array}{c}0.976 * * * \\
(0.191)\end{array}$ & $\begin{array}{c}0.443^{* *} \\
(0.174)\end{array}$ & $\begin{array}{c}0.226^{* * *} \\
(0.078)\end{array}$ \\
\hline Pseudo $\mathrm{R}^{2}$ & 0.05 & 0.06 & 0.05 & 0.06 & 0.05 \\
\hline Observations & 14,220 & 14,500 & 25,613 & 26,199 & 27,536 \\
\hline
\end{tabular}

NOTES: Robust standard errors are in parentheses. Significance levels are indicated by * for $10 \%$, ** for $5 \%$, and $* * *$ for $1 \%$. The dependent variable is the dummy indicating whether an individual is employed. Regressions control for years-since-migration, age group, educational attainment, knowledge of official languages, marital status, visible minority status and province of residence. The sample is restricted to male labour force participants (employed or unemployed) aged 25-54 living in Ontario, Quebec, Manitoba, Saskatchewan, Alberta, British Columbia. 
Table 7

Probit Regressions of Male Immigrant Employment: Marginal Effects of Large Enclave Dummy

\begin{tabular}{|c|c|c|c|c|c|}
\hline Census & $\begin{array}{c}(1) \\
1981 \\
\end{array}$ & $\begin{array}{c}(2) \\
1986 \\
\end{array}$ & $\begin{array}{c}(3) \\
1991 \\
\end{array}$ & $\begin{array}{c}(4) \\
1996 \\
\end{array}$ & $\begin{array}{c}(5) \\
2001\end{array}$ \\
\hline \multicolumn{6}{|l|}{ Regressions with No Interaction } \\
\hline Large Enclave Dummy & $\begin{array}{c}0.006^{* *} \\
(0.003)\end{array}$ & $\begin{array}{c}0.020 * * * \\
(0.004)\end{array}$ & $\begin{array}{c}0.017 * * * \\
(0.006)\end{array}$ & $\begin{array}{c}0.018^{* * *} \\
(0.006)\end{array}$ & $\begin{array}{l}0.011^{* *} \\
(0.004)\end{array}$ \\
\hline Pseudo $\mathrm{R}^{2}$ & 0.05 & 0.06 & 0.05 & 0.06 & 0.05 \\
\hline \multicolumn{6}{|c|}{ Regressions with Large Enclave Dummy Interacted with YSM Group } \\
\hline Large Enclave * YSM>20 & $\begin{array}{l}-0.003 \\
(0.006)\end{array}$ & $\begin{array}{c}0.011 \\
(0.007)\end{array}$ & $\begin{array}{c}0.006 \\
(0.007)\end{array}$ & $\begin{array}{c}0.003 \\
(0.006)\end{array}$ & $\begin{array}{c}0.000 \\
(0.006)\end{array}$ \\
\hline Large Enclave * YSM 11-20 & $\begin{array}{c}0.004 \\
(0.006)\end{array}$ & $\begin{array}{c}0.019 * * * \\
(0.006)\end{array}$ & $\begin{array}{c}0.009 \\
(0.008)\end{array}$ & $\begin{array}{c}0.011 \\
(0.010)\end{array}$ & $\begin{array}{l}0.013^{* *} \\
(0.005)\end{array}$ \\
\hline Large Enclave * YSM $<10$ & $\begin{array}{c}0.012 * * * \\
(0.004)\end{array}$ & $\begin{array}{c}0.026 * * * \\
(0.006)\end{array}$ & $\begin{array}{c}0.029 * * * \\
(0.008)\end{array}$ & $\begin{array}{c}0.028^{* * *} \\
(0.007)\end{array}$ & $\begin{array}{c}0.015^{* *} \\
(0.006)\end{array}$ \\
\hline $\begin{array}{l}\text { Pseudo } \mathrm{R}^{2} \\
\text { Observations }\end{array}$ & $\begin{array}{c}0.05 \\
14.220\end{array}$ & $\begin{array}{c}0.06 \\
14.500\end{array}$ & $\begin{array}{c}0.05 \\
25613\end{array}$ & $\begin{array}{c}0.06 \\
26109\end{array}$ & $\begin{array}{c}0.05 \\
27536\end{array}$ \\
\hline
\end{tabular}

NOTES: Same as Table 6. 
Table 8

IV Probit Regressions of Male Immigrant Labour Force Participation: Marginal Effects of Enclave Variables

\begin{tabular}{lcccc}
\hline Census & $(1)$ & $(2)$ & $(3)$ & $(4)$ \\
\hline & 1986 & 1991 & 1996 & 2001 \\
Enclave Exposure Index & -0.037 & 0.139 & $-0.444^{* * *}$ & $-0.394^{* * *}$ \\
& $(0.124)$ & $(0.198)$ & $(0.094)$ & $(0.123)$ \\
& & & & \\
$\mathrm{Rho}^{4}$ & 0.004 & -0.006 & 0.006 & 0.006 \\
\hline & & & & \\
Large Enclave Dummy & 0.001 & 0.009 & $-0.028^{* * *}$ & $-0.031^{* *}$ \\
& $(0.008)$ & $(0.008)$ & $(0.010)$ & $(0.014)$ \\
Rho & & & & \\
Observations & -0.024 & 0.017 & $0.055^{* * *}$ & $0.081^{* * *}$ \\
\hline
\end{tabular}

NOTES: Results from the second stage regressions are presented. Robust standard errors are in parentheses. Significance levels are indicated by $*$ for $10 \%$, ** for $5 \%$, and $* * *$ for $1 \%$. The dependent variable is the dummy indicating whether an individual participates in the labour force (employed or unemployed). Regressions control for years-since-migration, age group, educational attainment, knowledge of official languages, marital status, visible minority status and province of residence. The sample is restricted to males aged 25-54 living in Ontario, Quebec, Manitoba, Saskatchewan, Alberta, British Columbia.

\footnotetext{
${ }^{4}$ Rho measures the correlation between the errors in the probit equation and the reduced-form equation for the endogenous regressor. A rho that is significantly different from zero means one should reject the null hypothesis that there is no endogeneity issue and verifies the use of IV.
} 
Table 9

IV Probit Regressions of Male Immigrant Employment: Marginal Effects of Enclave Variables

\begin{tabular}{lcccc}
\hline & $(1)$ & $(2)$ & $(3)$ & $(4)$ \\
Census & 1986 & 1991 & 1996 & 2001 \\
\hline \multirow{2}{*}{ Enclave Exposure Index } & $0.395^{* *}$ & $0.592^{* * *}$ & $0.373^{* * *}$ & $0.153^{* *}$ \\
& $(0.193)$ & $(0.189)$ & $(0.107)$ & $(0.060)$ \\
& & & & \\
Rho & -0.010 & -0.016 & $-0.041^{* * *}$ & $0.018^{*}$ \\
\hline & & & & \\
Large Enclave Dummy & $0.032^{* * *}$ & $0.023^{* *}$ & $0.019^{* * *}$ & $0.013^{* *}$ \\
& $(0.009)$ & $(0.010)$ & $(0.007)$ & $(0.006)$ \\
Rho & & & & \\
Observations & $-0.077^{* *}$ & $-0.048^{* *}$ & -0.022 & -0.014 \\
\hline
\end{tabular}

NOTES: Results from the second stage regressions are presented. Robust standard errors are in parentheses. Significance levels are indicated by $*$ for $10 \%$, ** for $5 \%$, and $* * *$ for $1 \%$. The dependent variable is the dummy indicating whether an individual is employed. Regressions control for years-since-migration, age group, educational attainment, knowledge of official languages, marital status, visible minority status and province of residence. The sample is restricted to male labour force participants (employed or unemployed) aged 25-54 living in Ontario, Quebec, Manitoba, Saskatchewan, Alberta, British Columbia. 